\title{
Transformacja polskiego systemu podatkowego i jej wpływ na ukształtowanie się doradztwa podatkowego
}

Doradztwo podatkowe, jako quasi-zawód czy też rodzaj świadczonych usług, pojawiło się w Polsce w pierwszej połowie lat 90. XX w. jako naturalna konsekwencja wystąpienia co najmniej dwóch okoliczności: transformacji ustroju państwa polskiego oraz reformy systemu podatkowego.

Transformację ustroju Polski rozpoczęła nowelizacja Konstytucji ${ }^{1}$ z dnia 7 kwietnia 1989 r. ${ }^{2}$, która zapoczątkowała proces demokratycznych przemian prawnoustrojowych w Polsce. Nowelizacja ta dotyczyła w zasadzie struktury oraz sposobu powoływania naczelnych organów państwowych. Przywróciła ona dwie instytucje ustrojowe: drugą izbę parlamentu (Senat) oraz urząd prezydenta, ponadto wprowadziła do ustroju Polski elementy pluralizmu politycznego, co umożliwiło opozycji udział w życiu publicznym.

Najistotniejsze jednak znaczenie dla kształtowania się ustroju Polski miała nowela Konstytucji z dnia 29 grudnia 1989 r. ${ }^{3}$ Objęła ona swoim zakresem przede wszystkim podstawowe zasady ustroju politycznego i społeczno-gospodarczego. Fundamentalne znaczenie miało uchylenie tych przepisów Konstytucji, które odwoływały się w swej treści do ustroju „,państwa socjalistycznego”, przewodniej roli Polskiej Zjednoczonej Partii Robotniczej, szczególnej roli klasy robotniczej oraz deklaracji przyjaźni i współpracy ze Związkiem Radzieckim. Nowela ta przywróciła historyczną nazwę państwa polskiego - Rzeczpospolita Polska, zmieniono także godło państwowe na tradycyjnego orła w koronie. Ponadto do Rozdziału I Konstytucji - Podstawy ustroju politycznego i gospodarczego - wprowadzono:

* Mgr Elżbieta Agnieszka Ambrożej - Katedra Prawa i Europeistyki, Wyższa Szkoła Finansów i Zarządzania w Białymstoku.

1 Konstytucja Polskiej Rzeczypospolitej Ludowej uchwalona przez Sejm Ustawodawczy w dniu 22 lipca 1952 r., Dz. U. z 1976 r. Nr 7, poz. 36; z 1980 r. Nr 22, poz. 81; z 1982 r. Nr 11, poz. 83; z 1983 r. Nr 39, poz. 175; z 1987 r. Nr 14, poz. 82; z 1988 r. Nr 19, poz. 129.

2 Ustawa o zmianie Konstytucji Polskiej Rzeczypospolitej Ludowej z dnia 7 kwietnia 1989 r., Dz. U. Nr 19, poz. 101.

3 Ustawa o zmianie Konstytucji Polskiej Rzeczypospolitej Ludowej z dnia 29 grudnia 1989 r., Dz. U. Nr 75, poz. 444. 
1) nową definicję państwa polskiego: „Art. 1. Rzeczpospolita Polska jest demokratycznym państwem prawnym, urzeczywistniającym zasady sprawiedliwości społecznej";

2) nowe określenie podmiotu władzy najwyższej w państwie: „Art. 2.1. W Rzeczypospolitej Polskiej władza zwierzchnia należy do Narodu";

3) nową definicję praworządności (obowiązek przestrzegania prawa ciąży na organach państwa, a nie - jak dotychczas - także na obywatelach): „Art. 3.1. Przestrzeganie praw Rzeczypospolitej Polskiej jest podstawowym obowiązkiem każdego organu państwa. 2. Wszystkie organy władzy i administracji państwowej działają na podstawie przepisów prawa";

4) zasadę swobody tworzenia i działalności partii politycznych: „Art. 4.1. Partie polityczne zrzeszają na zasadach dobrowolności i równości obywateli Rzeczypospolitej Polskiej w celu wpływania metodami demokratycznymi na kształtowanie polityki państwa. 2. O sprzeczności z Konstytucją celów lub działalności partii politycznej orzeka Trybunał Konstytucyjny";

5) proklamowanie zasady udziału samorządu terytorialnego w sprawowaniu władzy państwowej oraz swobody działalności innych form samorządu: „Art. 5. Rzeczpospolita Polska gwarantuje udział samorządu terytorialnego w sprawowaniu władzy oraz swobodę działalności innych form samorządu".

Co istotne dla późniejszego kształtowania się nowego systemu podatkowego, zmianie uległy przepisy konstytuujące podstawy ustroju społeczno-gospodarczego. Zrezygnowano $\mathrm{z}$ takich zasad dotychczasowego ustroju, jak: dominacja własności państwowej, planowanie społeczno-gospodarczego, monopol państwa w dziedzinie handlu zagranicznego, a w to miejsce wprowadzono m.in. zasady:

1) równouprawnienia wszystkich form własności oraz zagwarantowanie każdemu podmiotowi swobody w prowadzeniu działalności gospodarczej4;

2) obowiązku ochrony własności i prawa do dziedziczenias.

Należy zwrócić uwagę, że zasada swobody działalności gospodarczej została proklamowana jeszcze przed jej włączeniem do Konstytucji RP nowelą z 29 grudnia 1989 r. Ustawa z dnia 23 grudnia 1988 r. o działalności gospodarczej ${ }^{6} \mathrm{w}$ art. 1 stanowiła: „Podejmowanie i prowadzenie działalności gospodarczej jest wolne i dozwolone każdemu na równych prawach, z zachowaniem warunków określonych przepisami prawa".

Nadanie zasadzie wolności gospodarczej rangi normy konstytucyjnej było niezwykle istotne. Stanowiło gwarancję, że wszystkie inne akty normatywne

${ }^{4}$ „Art. 6. Rzeczpospolita Polska gwarantuje swobodę działalności gospodarczej bez względu na formę własności; ograniczenie tej swobody może nastąpić jedynie w ustawie".

5 „Art. 7. Rzeczpospolita Polska chroni własność i prawo dziedziczenia oraz poręcza całkowitą ochronę własności osobistej. Wywłaszczenie jest dopuszczalne wyłącznie na cele publiczne i za słusznym odszkodowaniem".

${ }^{6}$ Dz. U. Nr 41, poz. 324. 
w Polsce będą z tą zasadą zgodne, a formalną gwarancją jej przestrzegania była możliwość dokonywania przez Trybunał Konstytucyjny kontroli ich konstytucyjności.

Można stwierdzić, że każda ze zmian wprowadzonych w życie mocą ustawy o zmianie Konstytucji Polskiej Rzeczypospolitej Ludowej z dnia 29 grudnia 1989 r. miała wpływ na kształtowanie się podstaw reformy systemu podatkowego. Każda kolejna zmiana Konstytucji, aż do uchwalenia nowej Konstytucji Rzeczypospolitej Polskiej 2 kwietnia 1997 r., była niejako konsekwencją wprowadzenia zmian nowelą grudniową ${ }^{7}$. Wydaje się jednak, że najistotniejsze znaczenie dla transformacji systemu podatkowego w Polsce miało zrównanie wszystkich form własności, obowiązek prawnej ochrony własności i prawa do dziedziczenia oraz zagwarantowanie każdemu podmiotowi swobody w prowadzeniu działalności gospodarczej.

Zmiana ustroju Polski - powodująca przejście od systemu socjalistycznego do kapitalistycznego - dokonała się niezwykle szybko. W jej konsekwencji pojawiła się konieczność dostosowania do nowych warunków systemu obciążeń podatkowych, w szczególności w odniesieniu do podmiotów prowadzących działalność gospodarczą.

W dalszej części opracowania wskazane zostaną tylko te elementy reformy systemu podatkowego, które w najistotniejszy sposób przyczyniły się do powstania w Polsce doradztwa podatkowego, a w konsekwencji do ukształtowania się zawodu doradcy podatkowego.

Reforma systemu podatkowego w Polsce rozpoczęła się na początku 1989 r., a więc tuż po wejściu w życie ustawy o działalności gospodarczej, a jeszcze przed transformacją ustrojową zapoczątkowaną w kwietniu $1989 \mathrm{r}$. Zmiany te zapoczątkowała uchwalona 31 stycznia 1989 r. ustawa o podatku dochodowym od osób prawnych ${ }^{8}$. Ustawa ta zniosła obowiązujący dotychczas podział podatków na obciążające tzw. jednostki gospodarki uspołecznionej (przedsiębiorstwa państwowe, spółdzielnie) i pozostałe podmioty (przedsiębiorstwa prywatne, osoby fizyczne, spółki z przewagą kapitału niepaństwowego). Należy przypomnieć, że podział ten był jednym z głównych mankamentów obowiązujących dotychczas regulacji obciążeń podatkowych, gdyż obciążenia podatkowe sektora nieuspołecznionego często były znacznie ostrzejsze niż sektora gospodarki uspołecznionej.

Zasadnicza zmiana systemu podatkowego nastąpiła już po 1990 r., kiedy to zreformowano większość obowiązujących w Polsce podatków. W pierwszym etapie reformy systemu podatkowego uregulowano zasady opodatkowania dochodu: najpierw dochodów osób fizycznych ustawą z dnia 26 lipca 1991 r. o podatku

${ }^{7}$ Na przykład proklamowana zasada udziału w sprawowaniu władzy samorządy terytorialnego, znalazła odbicie w kolejnej noweli Konstytucji z dnia 8 marca 1990 r. (Dz. U. Nr 16, poz. 94), która objęła terenowe struktury aparatu państwowego. Nowela zniosła system rad narodowych i terenowych organów administracji państwowej, wprowadzając w ich miejsce organy samorządu terytorialnego.

${ }^{8}$ Dz. U. Nr 3, poz. 12. 
dochodowym od osób fizycznych ${ }^{9}$, następnie dochodów osób prawnych ustawą z dnia 15 lutego 1992 r. o podatku dochodowym od osób prawnych oraz o zmianie niektórych ustaw regulujących zasady opodatkowania ${ }^{10}$.

Ustawa o podatku dochodowym od osób fizycznych jako zasadę wprowadziła powszechność opodatkowania dochodów osób fizycznych. Objęła swoim zakresem prawie wszystkie dochody osiągane przez osoby fizyczne, zastępując tym samym dotychczas obowiązujące podatki, tj. podatek dochodowy z 1972 r., podatek wyrównawczy, podatek od wynagrodzeń i od płac. Objęła także działy specjalne produkcji rolnej opodatkowane do tej pory podatkiem rolnym, a także znacząco ograniczyła bardzo rozpowszechnione w Polsce zryczałtowane formy opodatkowania osób prowadzących działalność gospodarczą. Podatnicy opodatkowani dotychczas na zasadach uproszczonych musieli opłacać podatki na zasadach ogólnych, tj. prowadząc podatkową księgę przychodów i rozchodów oraz składając deklaracje i zeznania podatkowe.

Ponadto, ustawa ustanowiła zasadę, iż zobowiązania podatkowe w podatku dochodowym od osób fizycznych powstają z mocy prawa jako rezultat wystąpienia przewidzianych przepisami tej ustawy stanów faktycznych. Ten sposób powstawania zobowiązań należy wiązać z wprowadzoną do polskiego systemu podatkowego zasadą samoobliczenia zobowiązania przez podatnika lub obliczenia przez płatnika. Ustawa nałożyła zatem na podatników (płatników) obowiązek samodzielnego obliczenia należnego podatku na deklaracji podatkowej według ustalonego wzoru i zapłaty tak obliczonego podatku w ściśle określonych terminach.

Analogiczne regulacje, dotyczące powszechności opodatkowania i samoobliczenia podatków, wprowadziła ustawa o podatku dochodowym od osób prawnych, a także uchwalona 8 stycznia 1993 r. ustawa o podatku od towarów i usług oraz o podatku akcyzowym ${ }^{11}$. Ustawa ta wprowadziła nowy, powszechny podatek od wartości dodanej, który zastąpił archaiczny podatek obrotowy. Obciążył on generalnie sprzedaż wszystkich towarów i usług.

Transformacja ustrojowa, a w szczególności wprowadzenie zasady wolności gospodarczej i równouprawnienia wszystkich form własności oraz reforma systemu podatkowego - w tym w szczególności wprowadzenie powszechności podatków: dochodowego od osób fizycznych, dochodowego od osób prawnych, a także podatku od towarów i usług oraz podatku akcyzowego - spowodowały, że nieporównywalnie ze stanem dotychczasowym zwiększyła się liczba podmiotów, osób fizycznych i osób prawnych, objętych obowiązkiem podatkowym. W rezultacie tych zmian, bezpośrednio po ich wprowadzeniu, powstało około dwóch milionów nowych podmiotów gospodarczych, objętych obowiązkami podatkowymi wynikającymi z różnych ustaw podatkowych oraz około kilkunastu milionów nowych podatników podatku dochodowego od osób fizycznych, zobli-

\footnotetext{
9 Dz. U. Nr 80, poz. 350.

10 Dz. U. Nr 21, poz. 86.

11 Dz. U. Nr 11, poz. 50.
} 
gowanych do samodzielnego rozliczania się z dochodów osiąganych ze stosunku pracy. Podatnicy ci w przeważającej liczbie przypadków nie posiadali jakichkolwiek tradycji podatkowych, a także dostatecznego poziomu edukacji podatkowej. Dotychczas obowiązujące przepisy prawa podatkowego nie nakładały na nich żadnych obowiązków związanych z prowadzeniem ksiąg podatkowych, wypełnianiem deklaracji czy zeznań podatkowych, dlatego też nowe otoczenie prawne okazało się, przynajmniej w pierwszych latach po wejściu w życie „,nowych podatków", dużym wyzwaniem.

W celu realizacji obowiązków podatkowych znaczna część podatników zmuszona była do korzystania z pomocy różnego rodzaju biur rachunkowych, podatkowych czy doradztwa podatkowego, które pojawiły się na rynku usług doradczych w sposób naturalny jako odpowiedź na wzrastający popyt na tego rodzaju usługi. Oczywiście, doradztwo podatkowe mogło być wykonywane przez adwokatów, radców prawnych i biegłych księgowych niejako „przy okazji” w ramach ich kompetencji zawodowych, lecz poza tymi przypadkami doradztwo podatkowe mogło być wykonywane bez szczególnych regulacji prawnych, na ogólnie obowiązujących zasadach dotyczących prowadzenia działalności gospodarczej przez osoby fizyczne oraz spółki cywilne tych osób, o ile dokonały zgłoszenia działalności do ewidencji podmiotów gospodarczych, a także spółki prawa handlowego, po spełnieniu warunków przewidzianych w Kodeksie handlowym. Przepisy prawa w żaden inny sposób nie ograniczały dostępu do wykonywania doradztwa podatkowego, ani poprzez cenzus wykształcenia, potwierdzenia posiadanych kwalifikacji zawodowych $\mathrm{w}$ drodze jakiegokolwiek egzaminu, odbytej praktyki zawodowej czy niekaralności.

Najistotniejszym problemem było to, iż podmioty świadczące usługi doradztwa podatkowego wyłączone były spod jakiejkolwiek kontroli jakości i poziomu świadczonych usług. Znaczna ich część okazała się nieuczciwa. Skutki ich nieuczciwości, niefachowości i nierzetelności w konsekwencji ponosili podatnicy, a w ogólnym rozrachunku także Skarb Państwa oraz jednostki samorządu terytorialnego.

Rzetelni doradcy podatkowi zaczęli organizować się w różnego rodzaju związki i stowarzyszenia o charakterze zawodowym (np. Stowarzyszenie Ekspertów Finansowych i Doradców Podatkowych, Ogólnopolskie Stowarzyszenie Właścicieli i Kierowników Biur Rachunkowych itp.) oraz dążyć do podnoszenia rangi ich zawodu, a tym samym jakości świadczonych usług. Miało to służyć zbudowaniu dobrych relacji i wzajemnego zaufania między doradcami podatkowymi i ich klientami, a także organami podatkowymi oraz zapewnić ochronę interesów podatników, zagwarantować zgodne z prawem stosowanie prawa podatkowego, co w gruncie rzeczy miałoby służyć ochronie interesów państwa. Dobrze naliczane i regularnie płacone podatki zapewniają bowiem permanentny dopływ środków finansowych do budżetu państwa oraz jednostek samorządu terytorialnego. Zarówno w interesie klientów, doradców podatkowych, a także państwa leżało więc doprowadzenie do sytuacji, w której w sposób jednoznaczny zostaną okre- 
ślone zasady prowadzenia usług doradztwa podatkowego i wymogi, jakie muszą spełnić doradcy podatkowi. Środowisko doradców podatkowych rozpoczęło kampanię zmierzającą do utworzenia w Polsce, wzorem innych państw, nowego wolnego zawodu doradcy podatkowego. Zakwalifikowanie zawodu doradcy jako zawodu wolnego miało przede wszystkim zagwarantować doradcom niezależność w wykonywaniu ich obowiązków i ochronę przed nieuczciwą konkurencją.

Potrzebę prawnej regulacji zasad wykonywania doradztwa podatkowego zauważył już w 1994 r. G. W. Kołodko - ówczesny wicepremier rządu, minister finansów, stwierdzając, że jednym ze środków służących zapewnieniu bezpieczeństwa gospodarczego jest ,przeciwdziałanie uszczupleniom podatkowym ze strony firm zarejestrowanych (minimalizacja obciążeń podatkowych i podobnych, nierzetelne ewidencjonowanie obrotów, kosztów, dochodów oraz wykorzystywanie umów-zleceń uszczuplające dochody ZUS) w drodze [...] popierania rozwoju instytucji doradców podatkowych przy konsekwentnym pozbawieniu ich prawa wykonywania zawodu w przypadku wykrycia nieuczciwości”. Jednocześnie autor zaznaczył, że rozpoczęto prace nad ustawą o koncesjonowaniu zawodu doradcy podatkowego ${ }^{12}$.

Postawa środowiska doradców podatkowych oraz stanowisko ministra finansów zaowocowały rozpoczęciem prac nad przygotowaniem projektu ustawy o doradztwie podatkowym. Projektodawca, kształtując ramy prawne zawodu doradcy podatkowego, wzorował się na niemieckim modelu doradztwa podatkowego, które na mocy ustawy z dnia 4 listopada 1975 r. o doradztwie podatkowym (Steuerberatungsgesetz) uregulowane zostało jako zawód koncesjonowany, do którego dostęp mają wyłącznie osoby posiadające odpowiednie kwalifikacje sprawdzone przez państwową komisję egzaminacyjną oraz licencję krajowych władz finansowych.

Rządowy projekt ustawy o doradztwie podatkowym wraz z uzasadnieniem wpłynął do Sejmu 23 czerwca 1995 r. ${ }^{13} \mathrm{Z}$ uzasadnienia do projektu ustawy o doradztwie podatkowym wynikało, że główną przesłanką jego przygotowania było utworzenie nowej grupy zawodowej uznanej przez państwo, która cieszyłaby się dużym zaufaniem i prestiżem społecznym, co było szczególnie istotne w dobie transformacji systemu podatkowego w Polsce. Usługi doradztwa podatkowego mieli wykonywać wysoko kwalifikowani specjaliści, których wiedzę i umiejętności praktyczne miała oceniać specjalnie do tego powołana Państwowa Komisja Egzaminacyjna do Spraw Doradztwa Podatkowego. Postawienie wysokich wymagań, których spełnienia od doradców wymagała ustawa, miało zapewnić stopniowe eliminowanie nieuczciwej konkurencji z rynku usług doradczych, a w konsekwencji ochronę praw podatników.

${ }^{12}$ G. W. Kołodko, Strategia dla Polski, Warszawa 1994, s. 82-85.

13 Rządowy projekt ustawy o doradztwie podatkowym, druk sejmowy nr 1113 z dnia 23 czerwca $1995 \mathrm{r}$. 
Wychodząc naprzeciw potrzebom rynku, Sejm Rzeczypospolitej Polskiej uchwalił 5 lipca 1996 r. ustawę o doradztwie podatkowym, która weszła w życie 1 stycznia 1997 r. Ustawa kształtująca zawód doradcy podatkowego została oparta na następujących założeniach:

1) czynności doradztwa podatkowego mogą być wykonywane wyłącznie przez uprawnione podmioty ${ }^{14}$;

2) listę doradców podatkowych wykonujących doradztwo podatkowe prowadzi samorząd zawodowy, który podejmuje też decyzje w przedmiocie wpisu na listę;

3) w celu ułatwienia podatnikom rozeznania, które podmioty są uprawnione do wykonywania doradztwa podatkowego, wprowadzono ustawowy tytuł zawodu „doradca podatkowy”, podlegający ochronie prawnej;

4) wykonywanie doradztwa podatkowego przez podmioty nieuprawnione podlega karze grzywny;

5) doradcy podatkowi nabywają ustawowy obowiązek ubezpieczenia odpowiedzialności cywilnej za szkody wyrządzone przy jego wykonywaniu;

6) doradcy podatkowi wpisani na listę doradców podatkowych są członkami Krajowej Izby Doradców Podatkowych, która stanowi ich samorząd zawodowy.

Ustawa nie zawierała definicji legalnej pojęcia „doradztwo podatkowe”, art. 2 ustawy określił jedynie zakres „czynności doradztwa podatkowego”, których wykonywanie podlegało reżimowy ustawy. Inne czynności, mimo że mogły dotyczyć problemów podatkowych, nie były doradztwem podatkowym w jej rozumieniu ${ }^{15}$. W pierwotnym brzmieniu ustawy do czynności doradztwa podatkowego należało:

- udzielanie podatnikom, płatnikom i inkasentom, na ich zlecenie lub na ich rzecz, porad, opinii i wyjaśnień z zakresu ich zobowiązań podatkowych;

- prowadzenie w imieniu i na rzecz podatników, płatników i inkasentów ksiąg podatkowych i innych ewidencji do celów podatkowych oraz udzielanie im pomocy w tym zakresie;

- sporządzanie, w imieniu i na rzecz podatników, płatników i inkasentów zeznań i deklaracji podatkowych lub udzielanie im pomocy w tym zakresie;

- występowanie w postępowaniu w zakresie sądowej kontroli decyzji administracyjnej.

${ }_{14}^{14}$ Podmiotami uprawnionymi do wykonywania doradztwa podatkowego były: osoby fizyczne wpisane na listę doradców podatkowych, adwokaci, radcowie prawni, biegli rewidenci oraz wymienione enumeratywnie w art. 4 ust. 1 ustawy spółki doradztwa podatkowego i inne jednostki organizacyjne, w tym: organizacje zawodowe, spółdzielnie, stowarzyszenia, izby gospodarcze, o ile przedmiotem ich działalności statutowej było świadczenie doradztwa podatkowego wyłącznie na rzecz swoich członków. Wyżej wymienione podmioty mogły wykonywać doradztwo podatkowe wyłącznie przez doradców podatkowych, radców prawnych i biegłych rewidentów zatrudnionych w tych podmiotach.

${ }_{15}$ W. Modzelewski, R. Janiec, Komentarz do ustawy o doradztwie podatkowym, Warszawa 1997, s. 14-15. 
Określony w art. 2 ust. 1 zakres czynności doradcy podatkowego nie zapewnił jednolitego rozumienia niektórych wymienionych wyżej czynności. Na przykład pkt 1 omawianego przepisu stanowił, że czynności doradztwa podatkowego obejmują udzielanie podatnikom, płatnikom i inkasentom na ich zlecenie lub na ich rzecz porad, opinii i wyjaśnień z zakresu ich zobowiązań podatkowych. Art. 2 ust. 1 obowiązującej w tym czasie ustawy o zobowiązaniach podatkowych ${ }^{16}$ stanowił, iż zobowiązaniem podatkowym jest wynikające z obowiązku podatkowego zobowiązanie do uiszczenia na rzecz Skarbu Państwa lub gminy świadczenia pieniężnego, zwanego dalej ,„podatkiem”. Analiza powyższego przepisu prowadziła do wniosku, że czynności doradztwa podatkowego, o których mowa w art. 2 ust. 1 pkt 1 ustawy o doradztwie podatkowym, obejmowały wąski ich zakres. Czynności te ograniczały się do udzielania porad, opinii i wyjaśnień podatnikowi, płatnikowi bądź inkasentowi w sprawie ustalenia kwoty zobowiązania podatkowego (a więc dotyczyły sytuacji, gdy obowiązek podatkowy już powstał) oraz postępowania związanego z regulowaniem tych zobowiązań. Jeżeli zatem porady, opinie czy wyjaśnienia udzielane podatnikowi, płatnikowi czy inkasentowi wykraczały poza problem konkretnego zobowiązania podatkowego, nie były czynnościami doradztwa podatkowego, a podmioty świadczące tego rodzaju usługi nie naruszały reżimu ustawy.

Już po wejściu w życie ustawy o doradztwie podatkowym pojęcie ,zobowiązanie podatkowe" zostało zdefiniowane w Ordynacji podatkowej17. Zgodnie z art. 5 tejże ustawy ,zobowiązaniem podatkowym jest wynikające z obowiązku podatkowego zobowiązanie podatnika do zapłacenia na rzecz Skarbu Państwa, województwa, powiatu albo gminy podatku w wysokości, w terminie oraz w miejscu określonych w przepisach prawa podatkowego". Odczytując dosłownie brzmienie omawianego przepisu, należałoby stwierdzić, że de facto, podobnie jak pod rządami ustawy o zobowiązaniach podatkowych, doradztwo podatkowe ograniczone zostało do kwestii związanych z wysokością zobowiązania podatkowego ${ }^{18}$, ewentualnie do miejsca oraz terminu jego zapłaty. Analiza uzasadnienia do projektu ustawy o doradztwie podatkowym prowadziła do wniosku, iż intencją ustawodawcy było objęcie zakresem doradztwa podatkowego każdej czynności doradztwa podatkowego z dziedziny prawa podatkowego, a nie tylko zobowiązań podatkowych ${ }^{19}$.

${ }^{16}$ Ustawa z dnia 19 grudnia 1980 r. o zobowiązaniach podatkowych, Dz. U. z 1993 r. Nr 108, poz. 486 ze zm.

17 Pierwotny tekst ustawy z dnia 29 sierpnia 1997 r. Ordynacja podatkowa, Dz. U. Nr 137, poz. 926.

${ }_{18}$ B. Brzeziński, M. Kalinowski, M. Masternak, A. Olesińska, Ordynacja podatkowa. Komentarz, Torun 2002, s. 27: „Wysokość podatku wynika bądź to z obliczenia, którego dokonuje organ podatkowy, podatnik albo płatnik podatku, bądź to wprost $\mathrm{z}$ aktu prawnego, jeżeli stanowi on nie o podstawie obliczenia podatku i stawkach podatkowych, ale wprost o kwocie należnego podatku".

19 Szerzej na ten temat: J. Wojnowski, Zakres przedmiotowy doradztwa podatkowego, „Biuletyn Skarbowy" 1997, nr 5, s. 1-2. 
Kontrowersje mogło budzić także, użyte w omawianym przepisie sformułowanie: ,[...] na ich zlecenie lub na ich rzecz [...]”. Oznaczało ono, że wykonanie powyższych czynności mogło być zlecone przez konkretnego podatnika, płatnika lub inkasenta, ale także czynności te mogły być zlecone przez inne podmioty. W związku z powyższym nasuwało się pytanie, czy udzielanie porad, opinii i wyjaśnień w sytuacji, gdy zlecającym był nie sam podatnik, płatnik czy inkasent, można było traktować jako czynność doradztwa podatkowego? Czynność taka była czynnością doradztwa podatkowego tylko, jeżeli porada, opinia czy wyjaśnienie dotyczyły konkretnego podatnika (płatnika lub inkasenta) ${ }^{20}$.

Wątpliwości budziło także pominięcie w treści art. 2 innych niż podatnik, płatnik i inkasent podmiotów, na rzecz których mogły być świadczone usługi doradztwa podatkowego - osób trzecich oraz następców prawnych podatników, płatników i inkasentów. Podmioty te, zgodnie z obowiązującymi wówczas przepisami ustawy o zobowiązaniach podatkowych, ponosiły odpowiedzialność za zaległości podatkowe podatnika ${ }^{21}$. W świetle Ordynacji podatkowej odpowiedzialność ta została bardziej doprecyzowana i rozszerzona.

Szereg kontrowersji budził także przepis art. 2 ust. 1 pkt 4, który zaliczył do czynności doradztwa podatkowego występowanie doradcy podatkowego w postępowaniu w zakresie sądowej kontroli decyzji administracyjnej. Zapis art. 2 ust. 1 pkt 4 był dosyć niefortunny i, jak należy domniemywać, niezgodny z wolą ustawodawcy, ponieważ z jego treści wynikało, iż doradca podatkowy mógł występować przez NSA w różnych sprawach, niekoniecznie dotyczących problematyki podatkowej.

Uprawnienie doradcy do zastępstwa procesowego zostało zakwestionowane przez środowisko prawnicze jako niezgodne z art. 87 Kodeksu postępowania cywilnego (przepisy tej ustawy były stosowane odpowiednio do postępowania przed NSA), który określał zamknięty krąg podmiotów uprawnionych do występowania w charakterze pełnomocnika procesowego strony, tj. adwokatów i radców prawnych. Przypomnieć należy, że jeszcze w okresie vacatio legis ustawy o doradztwie podatkowym do Sejmu wpłynęła prezydencka inicjatywa ustawodawcza zakładająca skreślenie kontrowersyjnego art. 2 ust. 1 pkt 4 jako „wadliwie skonstruowanego, przede wszystkim jednak sprzecznego z systemem prawa, a konkretnie $\mathrm{z}$ uregulowaniem $\mathrm{w}$ polskim prawie procesowym instytucji pełnomocnika procesowego"'22. Jednocześnie zaproponowano, aby doradca podatkowy mógł być pełnomocnikiem podatnika, płatnika i inkasenta w postępowaniu w zakresie sądowej kontroli decyzji administracyjnych wydawanych w sprawach podatkowych,

20 E. Sibrecht-Ośka, D. Trzaska, Komentarz do ustawy o doradztwie podatkowym, Warszawa 1997, s. 45; W. Modzelewski, R. Janiec, Ustawa o doradztwie podatkowym. Zasady wpisu warunkowego na listę doradców podatkowych, Warszawa 1996, s. 31-32.

${ }^{21}$ Art. 40-47 ustawy o zobowiązaniach podatkowych.

22 Por. wniosek Prezydenta Rzeczypospolitej Polskiej skierowany do Sejmu RP o odmowie podpisania ustawy z 28 sierpnia 1997 r. o zmianie ustawy o doradztwie podatkowym. 
ale występowanie doradcy podatkowego w charakterze pełnomocnika strony w postępowaniu przed NSA nie miało być czynnością doradztwa podatkowego, lecz uprawnieniem doradcy podatkowego.

Sejm 28 sierpnia 1997 r. uchwalił tekst znowelizowanej ustawy o doradztwie podatkowym, której podpisania z kolei odmówił Prezydent, przesyłając ją do ponownego rozpatrzenia przez Sejm. Ostatecznie art. 2 ust. 1 pkt 4 został utrzymany w mocy, w pierwotnym brzmieniu.

Przepis art. 2 ust. 1 pkt 4 budził także wątpliwości judykatury. W kontrowersyjnym wyroku NSA w Lublinie ${ }^{23}$ sąd stwierdził, że na podstawie art. $87 \S 1$ Kodeksu postępowania cywilnego ${ }^{24}$, w związku z art. 59 ustawy o NSA ${ }^{25}$, pełnomocnikiem strony może być wyłącznie adwokat lub radca prawny, a ponadto współuczestnik sporu, jak również rodzice, małżonek, rodzeństwo lub zstępni strony oraz osoby pozostające ze stroną w stosunku przysposobienia. ,Z cytowanych przepisów ani z żadnych innych przepisów prawa nie wynika, aby pełnomocnikiem strony w postępowaniu przed Naczelnym Sądem Administracyjnym (inaczej jak w postępowaniu administracyjnym - por. art. $33 \S 1$ Kodeksu postępowania administracyjnego ${ }^{26} \mathrm{i}$ art. 41 ustawy o doradztwie podatkowym) mógł być doradca podatkowy”. Z tego też względu, zdaniem sądu, „Doradca podatkowy może występować przed Naczelnym Sądem Administracyjnym w postępowaniu w zakresie sądowej kontroli decyzji administracyjnej, jednak nie jako pełnomocnik procesowy strony, ale w szczególnym charakterze doradcy podatkowego, tj. osoby, która udziela stronie porady, opinii i wyjaśnień z zakresu zobowiązań podatkowych, prowadzenia ksiąg podatkowych, sporządzania deklaracji i zeznań podatkowych. Nie może więc wprawdzie dokonywać w imieniu strony czynności procesowych, jednak aktywnie wspiera ją w przedstawianiu i obronie merytorycznego stanowiska w sprawie".

Ustawa o doradztwie podatkowym doczekała się wielu nowelizacji, przy czym żadna $\mathrm{z}$ nich nie wpłynęła w istotny sposób na obowiązujący w Polsce od 1997 r. model doradztwa podatkowego, choć próba taka została podjęta przez ministra finansów w 1999 r. ${ }^{27}$ Nie uzyskała ona jednak aprobaty parlamentu.

${ }^{23}$ Wyrok NSA w Lublinie z dnia 4 grudnia 1998 r., sygn. akt I S.A./Lu1687/98, LEX nr 37652.

${ }^{24}$ Ustawa z dnia 17 listopada 1964 r. Kodeks postępowania cywilnego, Dz. U. Nr 43, poz. 296 ze zm.

${ }^{25}$ Ustawa z dnia 11 maja 1995 r., Dz. U. Nr 74, poz. 368 ze zm.

${ }^{26}$ Ustawa z dnia 14 czerwca 1960 r. t.j. Dz. U. z 1980 r. Nr 9, poz. 26 ze zm.

${ }^{27}$ Minister finansów przygotował projekt ustawy o zmianie ustawy o doradztwie podatkowym, który ku zdziwieniu środowiska doradców podatkowych zakładał de facto likwidację dopiero co powstałego, wolnego zawodu doradcy podatkowego wraz z jego samorządem zawodowym. W uzasadnieniu do projektu ustawy stwierdzono: „Podstawowym celem przedstawionego projektu jest zniesienie systemowych ograniczeń dostępności do wykonywania zawodu doradcy podatkowego. Uznano, że dotychczasowe rozwiązania przewidujące daleko idącą ingerencję administracyjną w uzyskiwanie uprawnień doradcy podatkowego są sprzeczne z podstawowymi założeniami społecznej gospodarki rynkowej. Wykonywanie tego zawodu powinno następować w warunkach 
W dobrym kierunku natomiast poszły m.in. zmiany ustawy dotyczące określenia zakresu czynności doradztwa podatkowego. Wynikały one przede wszystkim ze zmieniających się nieustannie przepisów prawa podatkowego (co wiązało się np. z wejściem Polski do Unii Europejskiej i koniecznością dostosowania polskich regulacji podatkowych do unijnych dyrektyw), a także z zawodowych doświadczeń samych doradców podatkowych. Przede wszystkim treść art. 2 ustawy o doradztwie podatkowym zmieniała się, wychodząc naprzeciw otoczeniu prawnemu podatników, potrzebom rynku, a w szczególności samych podatników. Zakres czynności doradztwa podatkowego zmieniało kilka nowelizacji ustawy ${ }^{28}$, a ostateczny kształt czynnościom doradztwa podatkowego nadała nowelizacja ustawy z dnia 10 czerwca $2010 \mathrm{r}$. Obecnie czynności doradztwa podatkowego obejmują udzielanie podatnikom, płatnikom i inkasentom, na ich zlecenie lub na ich rzecz, porad, opinii i wyjaśnień z zakresu ich obowiązków podatkowych i celnych oraz w sprawach egzekucji administracyjnej związanej z tymi obowiązkami (w tekście pierwotnym ustawy - wyłącznie z zakresu zobowiązań podatkowych). Ponadto, przyznano doradcy podatkowemu prawo do sporządzania opinii i wyjaśnień także w sprawach dotyczących odpowiedzialności płatników i inkasentów, wynagrodzeń płatników z tytułu realizacji obowiązków wynikających z pełnienia tej funkcji, obowiązków rejestracyjnych podatników oraz płatników, a także w innych kwestiach, które są związane z problematyką podatkową 29 . Rozszerzono zakres podmiotowy wykonywania czynności doradztwa podatkowego także na rzecz osób trzecich odpowiedzialnych za zaległości podatkowe oraz następców prawnych podatników, płatników i inkasentów (w tekście pierwotnym ustawy - wyłącznie na rzecz podatników, płatników i inkasentów).

Do czynności doradztwa podatkowego zaliczono ostatecznie reprezentowanie podatników, płatników i inkasentów w postępowaniu przed organami administracji publicznej i w zakresie sądowej kontroli decyzji, postanowień i innych aktów administracyjnych w sprawach dotyczących udzielania podatnikom, płatnikom i inkasentom, na ich zlecenie lub na ich rzecz, porad, opinii i wyjaśnień z zakresu ich obowiązków podatkowych i celnych oraz w sprawach egzekucji administracyjnej związanej z tymi obowiązkami (pierwotnie - występowanie w postępowaniu w zakresie sądowej kontroli decyzji administracyjnej).

wolnej konkurencji, w następstwie czego zostanie zapewniony szerszy dostęp do korzystania z tego rodzaju usług. Doradcy podatkowi, którzy okażą się niekompetentni bądź ich kwalifikacje okażą się niewystarczające, będą eliminowani w sposób naturalny z rynku usług doradztwa podatkowego. Tym samym więc tak głęboką ingerencję administracji publicznej w kształtowanie się tego rynku należy uznać za zbędną". Zob. uzasadnienie do projektu ustawy o zmianie ustawy o doradztwie podatkowym z dnia 4 października 1999 r., druk sejmowy nr 1411.

${ }^{28}$ Zmiany treści art. 2 ustawy o doradztwie podatkowym dokonano nowelami ustawy: $\mathrm{z}$ dnia 11 kwietnia 2001 r. (Dz. U. Nr 42, poz. 474), z dnia 16 grudnia 2004 r. (Dz. U. z 2005 r. Nr 10, poz. 66), z dnia 24 listopada 2007 r. (Dz. U. Nr 226, poz. 1674) oraz z dnia 10 czerwca 2010 r. (Dz. U. Nr 122, poz. 826).

${ }^{29}$ Szerzej na ten temat: Z. Banasiak, Ustawa o doradztwie podatkowym-komentarz do nowelizacji, „Forum Doradztwa Podatkowego” 2001, nr 6. 
Podsumowując, należy stwierdzić, że określony w obecnie obowiązującej ustawie o doradztwie podatkowym zakres czynności doradztwa podatkowego wzmacnia rolę i pozycję doradcy podatkowego, a - co najważniejsze - zapewnia jego klientowi profesjonalną usługę o szerokim zakresie. Wynika to nie tylko z faktu rozszerzenia zakresu czynności doradztwa podatkowego, ale także m.in. z faktu przyznania doradcom podatkowym możliwości tworzenia spółek multidyscyplinarnych (również z adwokatami i radcami prawnymi) oraz udzielania substytucji adwokatom i radcom prawnym, przez co klienci doradców podatkowych mogą liczyć na kompleksową, bardziej sprawną i profesjonalną obsługę przy prowadzeniu ich spraw, a tym samym na rzetelną ochronę przysługujących im uprawnień i praw. Było to, o czym należy pamiętać, podstawową przesłanką powołania do życia w Polsce regulowanego zawodu doradcy podatkowego.

Prawo podatkowe nieustannie ewoluuje. Należy do tych gałęzi prawa, które ulegają najczęstszym zmianom. O tym, że można mieć duże zastrzeżenia co do jakości ustaw podatkowych, świadczą liczne wątpliwości interpretacyjne przepisów prawa podatkowego, a także zdarzające się niejednolite interpretacje indywidualne dotyczące tych samych przepisów prawa podatkowego w analogicznych sytuacjach (w skrajnych sytuacjach interpretacje te wykluczały się wzajemnie ${ }^{30}$ ). Zapewnienie przez doradców podatkowych profesjonalnej pomocy podatnikom w zakresie realizacji ich obowiązków podatkowych wydaje się jak najbardziej uzasadnione. $Z$ pewną obawą należy zatem oceniać coraz częściej pojawiające się doniesienia prasowe o planach deregulacji zawodu doradcy podatkowego ${ }^{31}$. Należy mieć nadzieję, że o ile zapowiedzi te urzeczywistnią się, charakter i zakres zmian w prawie nie wpłynie negatywnie na jakość świadczonych usług doradztwa podatkowego, a tym samym na ochronę praw podatników.

${ }^{30}$ Por. interpretację indywidualną, sygn. IBPBI/2/423-709/09/SD, wydaną przez Dyrektora Izby Skarbowej w Katowicach, oraz interpretację indywidualną wydaną przez Dyrektora Izby Skarbowej w Bydgoszczy, uchyloną wyrokiem Wojewódzkiego Sądu Administracyjnego w Gdańsku z dnia 22 marca 2011 r., sygn. akt I SA/Gd 1311/10, LEX nr 784836. Istotą obu interpretacji były analogiczne pytania postawione przez dwie spółki: „Czy w związku z faktem prowadzenia działalności na terenie Specjalnej Strefy Ekonomicznej i korzystania ze zwolnienia z podatku dochodowego od osób prawnych, o którym mowa w art. 17 ust. 1 pkt 34 ustawy o p.d.o.p., Spółka może funkcjonować jako członek podatkowej grupy kapitałowej, która będzie podatnikiem, o którym mowa w art. 1a ust. 1 ww. ustawy?" Na powyższe pytanie Dyrektor Izby Skarbowej w Katowicach odpowiedział twierdząco, zaś Dyrektor Izby Skarbowej w Bydgoszczy - negatywnie. Wojewódzki Sąd Administracyjny w Gdańsku, po rozpatrzeniu przedmiotowej skargi na interpretację indywidualną, uznał: „Za podatnika podatku dochodowego od osób prawnych można uznać podatkową grupę kapitałową, o ile po utworzeniu tej grupy spółki ją tworzące nie korzystają ze zwolnień od podatku dochodowego na podstawie odrębnych ustaw. Jeśli spółki korzystają ze zwolnień przyznanych w ustawach podatkowych, to nie ma przeszkód, aby podatkową grupę kapitałową uznać za podatnika". Tym samym sąd uchylił zaskarżoną indywidualną interpretację oraz określił, że zaskarżona indywidualna interpretacja nie może być wykonana.

${ }^{31}$ Ł. Zalewski, Deregulacja: doradca podatkowy bez licencji nie będzie ukarany, „Dziennik Gazeta Prawna", 16 marca 2012, nr 54. 